\title{
Fasting plasma peptide-YY concentrations are elevated but do not rise postprandially in type 2 diabetes
}

\author{
P. J. English • A. Ashcroft • M. Patterson • T. M. Dovey • \\ J. C. G. Halford • J. Harrison • D. Eccleston • \\ S. R. Bloom • M. A. Ghatei • J. P. H. Wilding
}

Received: 25 April 2006 / Accepted: 20 May 2006 / Published online: 11 July 2006

(C) Springer-Verlag 2006

To the Editor:

Weight loss appears to be particularly difficult to achieve in patients with type 2 diabetes compared to their non-diabetic counterparts [1].

The hormones peptide $\mathrm{YY}_{3-36}$ (PYY) and ghrelin are implicated in the regulation of appetite, energy balance and the pathophysiology of obesity. PYY is released from L-cells in the gut in response to food [2]. Fasting concentrations are lower and postprandial responses attenuated in obese subjects [3], and infusions of PYY to mimic the postprandial concentrations found in lean subjects reduce appetite and food intake in obese subjects [3, 4], suggesting a potential role in the pathogenesis of obesity.

Peripheral administration of ghrelin increases food ingestion [5, 6], and prolonged administration leads to obesity $[5,7]$. Circulating ghrelin shows preprandial peaks and postprandial troughs suggesting a role in meal initiation.

P. J. English $(\bowtie) \cdot$ J. P. H. Wilding

Diabetes and Endocrinology Research Group,

Clinical Sciences Centre, University Hospital Aintree,

Longmoor Lane,

Liverpool L9 7AL, UK

e-mail: patrick.english@phnt.swest.nhs.uk

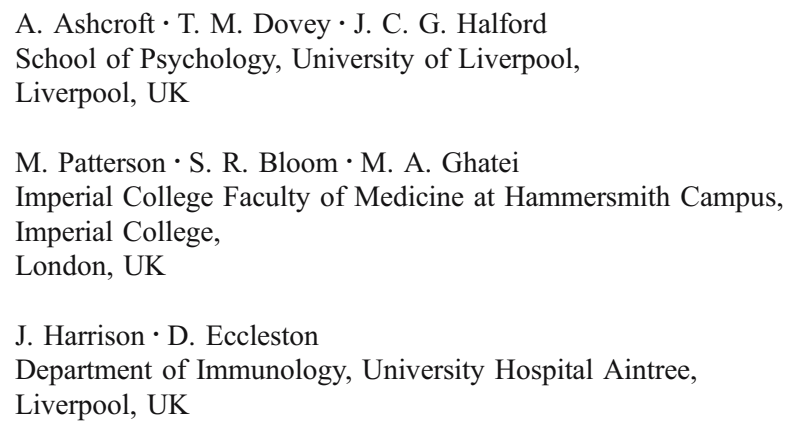

Against this background, we sought to determine whether type 2 diabetes, independent of obesity status, affected the prandial regulation of PYY and ghrelin in a manner that would explain both the predisposition to increased energy intake and weight gain, and the difficulties in achieving weight loss seen in type 2 diabetes.

The study was approved by the local ethics committee and subjects, who were volunteers, gave written informed consent.

We studied 11 subjects with diet-controlled type 2 diabetes and 16 control subjects of similar age, sex and BMI. All subjects with diabetes were free from complications and had an $\mathrm{HbA}_{1 \mathrm{c}}<10 \%$. Urea, electrolytes, full blood count, thyroid function and resting electrocardiogram were normal in all subjects. Antihypertensive, lipid-lowering and aspirin treatment were not considered exclusion criteria unless they included beta-adrenoreceptor antagonists.

Subjects attended at $08.30 \mathrm{~h}$, having fasted from $22.00 \mathrm{~h}$ the previous evening and refrained from alcohol or strenuous physical activity for at least $24 \mathrm{~h}$ and cigarettes for at least $12 \mathrm{~h}$. Anthropometric variables were measured and body fat percentage estimated using whole-body bioelectrical impedance analysis (Tanita Systems, Stokie, IL, USA). Studies were conducted at an ambient temperature of $22 \pm 1^{\circ} \mathrm{C}$.

Following baseline blood samples, subjects consumed a standard mixed meal of $600 \mathrm{kcal}(63.9 \%$ carbohydrate, $13.0 \%$ protein, $23.1 \%$ fat) over $20 \mathrm{~min}$. Blood was collected at 15, 30, 60, 120, 180, 240, 300 and $360 \mathrm{~min}$ after the meal. Samples were centrifuged, frozen immediately and stored at $-80^{\circ} \mathrm{C}$ until assayed. Plasma PYY-like immunoreactivity (specifically $\mathrm{PYY}_{3-36}$ and $\mathrm{PYY}_{1-36}$ with no cross-reactivity with other peptides) was measured using an established radioimmunoassay [2]. Ghrelin-like immunoreactivity was measured with a specific and sensitive 
Table 1 Baseline characteristics of type 2 diabetic and control subjects

\begin{tabular}{|c|c|c|c|}
\hline & $\mathrm{T} 2 \mathrm{D}(n=11)$ & Controls $(n=16)$ & $p$ value \\
\hline Male & 6 & 8 & \\
\hline Age in years, mean (SD) & $51.5(9.1)$ & $51.1(8.3)$ & NS \\
\hline BMI $\left(\mathrm{kg} / \mathrm{m}^{2}\right)$, median (IQR) & $32.2(13.9)$ & $34.3(9.1)$ & NS \\
\hline Waist (cm), median (IQR) & $98.5(29)$ & $105.0(17.5)$ & NS \\
\hline Body fat (\%), median (IQR) & $38.0(22)$ & $45.8(18.3)$ & NS \\
\hline Ghrelin (pmol/l), mean $(95 \% \mathrm{CI})$ & $377(301-501)$ & $458(391-614)$ & NS \\
\hline Leptin $(\mathrm{ng} / \mathrm{ml})$, mean $(95 \% \mathrm{CI})$ & $29.9(18.6-62.1)$ & $34.8(30.0-58.3)$ & NS \\
\hline PYY $(\mathrm{pmol} / 1)$, mean $(95 \% \mathrm{CI})$ & $19.8(17.5-22.8)$ & $13.8(11.6-18.1)$ & 0.0057 \\
\hline
\end{tabular}

T2D Diet-treated type 2 diabetic subjects, $D M$ diabetes mellitus, IQR interquartile range (distance between the top of the first and bottom of the fourth quartiles)

radioimmunoassay [8]; leptin, insulin and glucose were assayed using commercially available assays.

Resting metabolic rate and postprandial thermogenesis were measured by indirect calorimetry (Deltatrac Metabolic Monitor; Datex-Ohmeda, Helsinki, Finland).
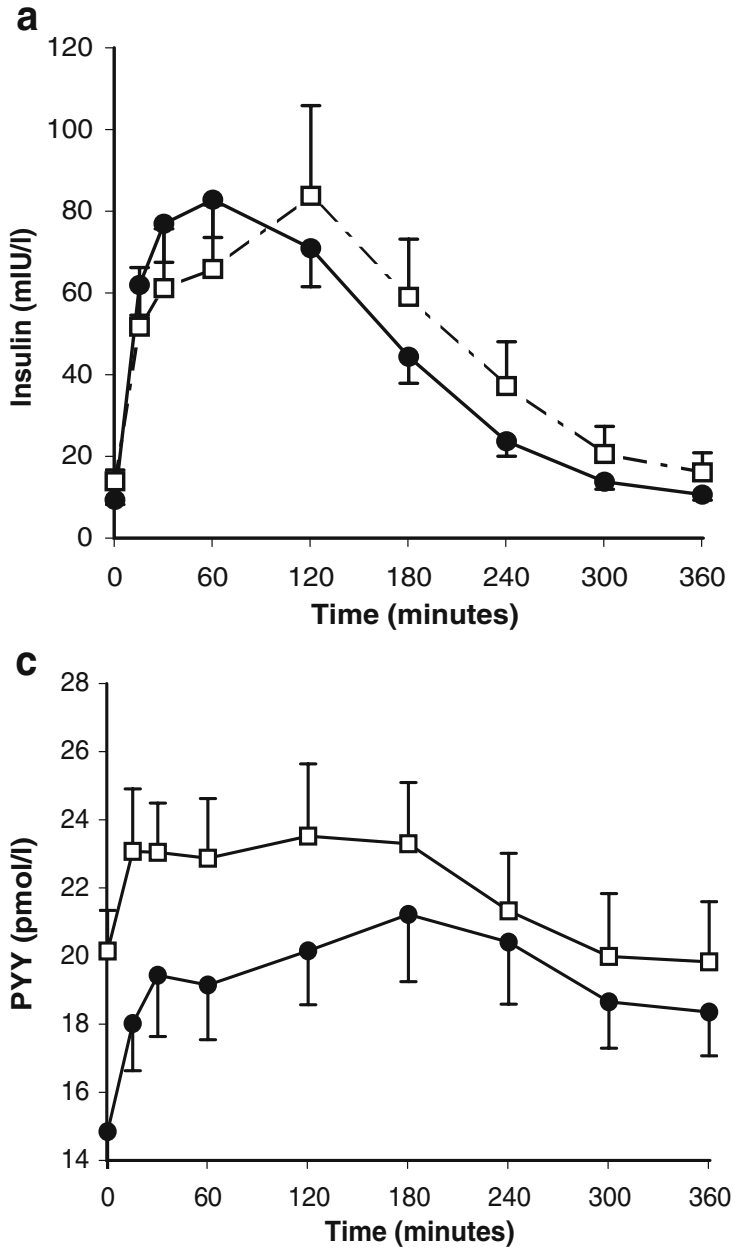

Statistical analysis was performed using StatsDirect statistical software version 1.9.7 (StatsDirect, Sale, Cheshire, UK; http://www.statsdirect.com).

The clinical characteristics were similar in diabetic and non-diabetic subjects (Table 1). Fasting PYY concentrations were $43.5 \%$ greater in diabetic subjects than in their non-diabetic counterparts (mean [95\% CI]: 19.8 [17.5-
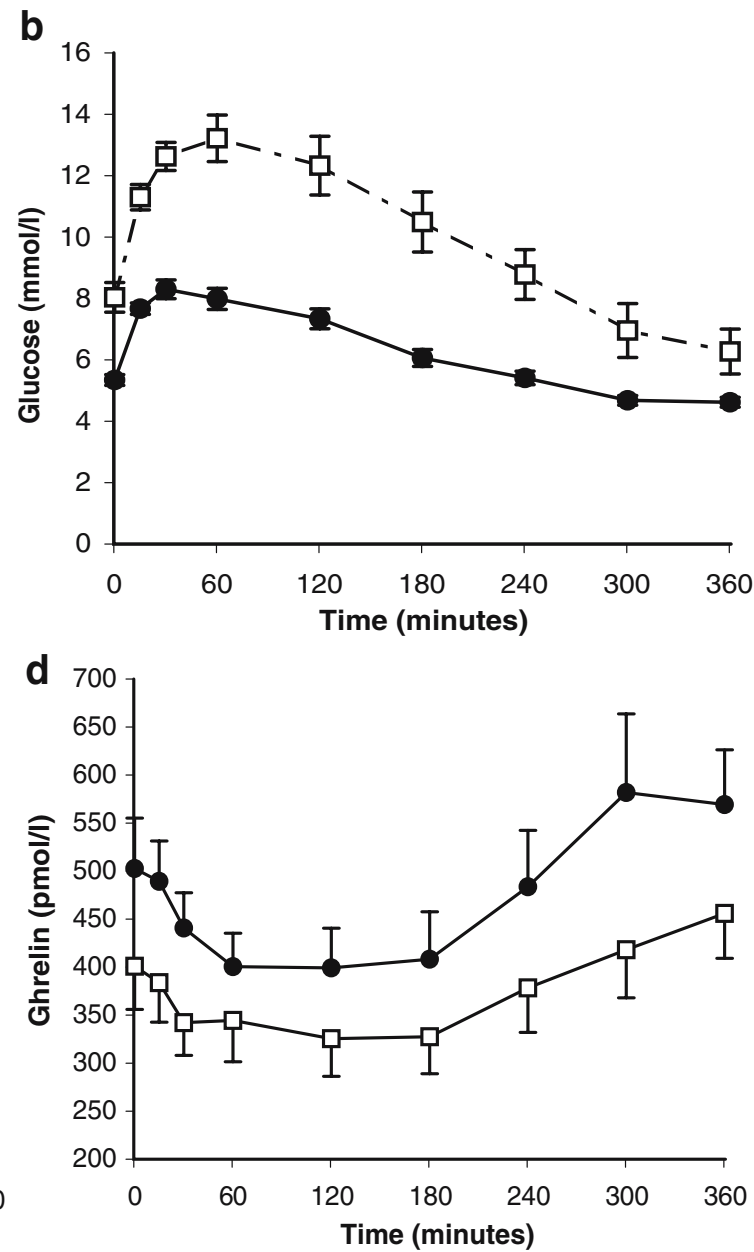

Fig. 1 Postprandial insulin (a), glucose (b), PYY (c), and ghrelin (d) concentrations, responses in diet-treated subjects with type 2 diabetes (open squares) and controls (black circles) 
$22.8]$ vs 13.8 [11.6-18.1] pmol/1, $p=0.0057$ ), with concentrations comparable to those seen postprandially in lean subjects (data not shown).

Resting metabolic rate, postprandial thermogenesis and non-protein respiratory quotient were similar in both groups, even after adjustment for fat-free mass.

Peak insulin concentrations and the AUC insulin (median [interquartile range, distance between top of first and bottom of fourth quartiles]: $10,846[10,767]$ vs 12,559

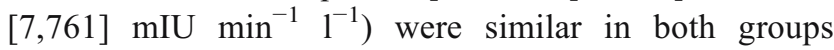
(Fig. 1a). Peak glucose values were $60 \%$ higher $(13.2 \pm 2.5$ vs $8.3 \pm 1.2 \mathrm{mmol} / \mathrm{l}, \mathrm{p}<0.0001)$ and AUC glucose $120 \%$ greater $\left(717 \pm 389\right.$ vs $\left.326 \pm 274 \mathrm{mmol} \mathrm{min}{ }^{-1} \mathrm{l}^{-1}, p=0.0027\right)$ in diabetic subjects (Fig. 1b).

In diabetic subjects PYY concentrations did not rise significantly after eating, although they increased by $63.6 \%$ in the control group (Fig. 1c). Fasting values in diabetic subjects and peak values in control subjects were similar to those seen at peak in lean subjects (unpublished data). Plasma ghrelin fell postprandially to a comparable degree in both groups $(23 \%$ type 2 diabetes vs $19 \%$ controls, $p=\mathrm{NS}$ ) (Fig. 1d).

We found that subjects with type 2 diabetes had higher fasting plasma concentrations of PYY than non-diabetic control persons of similar age, weight and sex. Moreover, PYY concentrations did not rise in response to food intake in type 2 diabetic patients, while fasting and prandial regulation of ghrelin, leptin and energy expenditure were unaffected by type 2 diabetes in patients with good glycaemic control.

The close similarities in age, sex, body weight and body fat between diabetic and control groups allowed us to distinguish between the effects of obesity and those of type 2 diabetes. We studied patients with type 2 diabetes of short duration (median duration 3 years), whose diabetes was well controlled by diet (mean $\mathrm{HbA}_{1 \mathrm{c}} 7.0 \%$ ), and who were free from macrovascular and microvascular complications (only four subjects on antihypertensive medication). This allowed the effects of type 2 diabetes to be studied in isolation from the effects of its treatment or vascular complications.

In obesity, in the presence of insulin resistance and a higher fasting glucose concentration than in lean subjects, PYY concentrations are lower than in lean subjects and increase in response to feeding (unpublished observations by the authors; Batterham et al. [3]). Therefore, the changes seen in diabetes cannot be attributed to the obese state, hyperglycaemia or insulin resistance.

Since the initial increase in PYY concentrations postprandially is neurally mediated, the possible presence of subclinical gut neuropathy in diabetic patients provides a potential explanation for the absence of a rise in PYY concentrations immediately after food intake. The response of GLP-1, another L-cell product, is also decreased postprandially [9, 10]. Elevated fasting concentrations of PYY may be due to increased secretion, increased release or decreased clearance. Both PYY and GLP-1 are degraded by dipeptidyl peptidase IV, the activity of which may be altered in type 2 diabetes $[11,12]$. However, contrary to our finding of markedly elevated PYY concentrations, GLP-1 concentrations are either decreased or normal in the fasted state in type 2 diabetes $[9,10]$. Altered activity of dipeptidyl peptidase IV is therefore an unlikely explanation for our results. Similarly, the potential for altered availability of nutrients to L-cells in type 2 diabetes might be expected to affect the secretion of PYY and GLP-1, but would be expected to affect them in the same manner. Thus neither of these possibilities provides a clear explanation for our results in the fasted state.

The question of how these perturbations in the regulation of PYY concentrations in patients with type 2 diabetes could be linked to the tendency to weight gain observed in other studies remains as yet unanswered. Further research is crucial to elucidate (1) the mechanisms underlying the regulation of plasma PYY concentrations, (2) how these differ from those regulating GLP-1 concentrations, and (3) to explain the differences seen in type 2 diabetes.

\section{References}

1. Wing RR, Marcus MD, Epstein LH, Salata R (1987) Type II diabetic subjects lose less weight than their overweight nondiabetic spouses. Diabetes Care 10:563-566

2. Adrian TE, Ferri GL, Bacarese-Hamilton AJ, Fuessl HS, Polak JM, Bloom SR (1985) Human distribution and release of a putative new gut hormone, peptide YY. Gastroenterology 89:1070-1077

3. Batterham RL, Cohen MA, Ellis SM et al (2003) Inhibition of food intake in obese subjects by peptide YY3-36. N Engl J Med 349:941-948

4. Batterham RL, Cowley MA, Small CJ et al (2002) Gut hormone PYY (3-36) physiologically inhibits food intake. Nature 418:650-654

5. Wren AM, Small CJ, Abbott CR et al (2001) Ghrelin causes hyperphagia and obesity in rats. Diabetes 50:2540-2547

6. Wren AM, Seal LJ, Cohen MA et al (2001) Ghrelin enhances appetite and increases food intake in humans. J Clin Endocrinol Metab 86:5992

7. Tschop M, Smiley DL, Heiman ML (2000) Ghrelin induces adiposity in rodents. Nature 407:908-913

8. English PJ, Ghatei MA, Malik IA, Bloom SR, Wilding JP (2002) Food fails to suppress ghrelin levels in obese humans. J Clin Endocrinol Metab 87:2984-2987

9. Toft-Nielsen MB, Damholt MB, Madsbad S et al (2001) Determinants of the impaired secretion of glucagon-like peptide- 1 in type 2 diabetic patients. J Clin Endocrinol Metab 86:3717-3723

10. Vilsboll T, Agerso H, Krarup T, Holst JJ (2003) Similar elimination rates of glucagon-like peptide- 1 in obese type 2 diabetic patients and healthy subjects. J Clin Endocrinol Metab 88:220-224

11. Meneilly GS, Demuth HU, McIntosh CH, Pederson RA (2000) Effect of ageing and diabetes on glucose-dependent insulinotropic polypeptide and dipeptidyl peptidase IV responses to oral glucose. Diabet Med 17:346-350

12. Mannucci E, Pala L, Ciani S et al (2005) Hyperglycaemia increases dipeptidyl peptidase IV activity in diabetes mellitus. Diabetologia 48:1168-1172 